В. А. Гаманюк

канд. пед. наук, доцент

\title{
ФУНКЦІОНАЛЬНІ ОСОБЛИВОСТІ ВИКОРИСТАННЯ ЗАПОЗИЧЕНЬ У НІМЕЦЬКІЙ МОВІ
}

У статті розглянуто проблему функиіонування запозичень з англійської мови та особливості їх використання в німецькій мові, а також можливості асиміляиії іншомовних слів та їх словотвірна продуктивність.

Проблема запозичень та їх використання в мові, особливо англіцизмів, $\epsilon$ актуальною для всіх без винятку мов. Це пов'язано в першу чергу з тим, що за останні 10-20 років кількість запозичених з англійської мови слів суттєво зросла. Ставлення до іншомовних слів та запозичень протягом століть було неоднозначним. Так, у певні періоди історичного розвитку мови запозичення сприймалися як шлях збагачення ії словникового складу, а сам процес розглядався як позитивне явище. В історії національних мов були також періоди активної боротьби з іншомовними словами, коли пуризм ставав вимогою часу. Контакти з іншими народами та пов'язаний 3 ними обмін інформацією, досвідом, матеріальними досягненнями залишали свій слід не тільки в суспільному житті, але й у мові. В епоху середньовіччя інтенсивне збагачення лексичного шару словами іншомовного походження, на відміну від сьогодення, не сприймалося в німецькій мові як катастрофа. Запозичення з латини, грецької мови, а також значна кількість слів із французької мови, які потрапили в німецьку під впливом лицарської культури, - це назви нових для Німеччини понять, предметів та явищ, що увійшли не тільки до мови, але стали повсякденням німецького суспільства, наприклад: Abenteuer, Kreuz, Kirche, Turnier, Posaune тощо. У період Відродження запозичення були, як правило, з латини і мали дидактичний характер. Серед них Argument, artikulieren, Disziplin, diskutieren, Element, formieren, Magister, Konzept, Universität, Substanz, Position, Klasse. Усі ці слова формують сьогодні лексичний склад більшості європейських мов, а не тільки німецької. Що стосується XVII століття, то в цей час через особливості історичного розвитку Німеччини (Тридцятирічна війна 16181648pp.) та значний вплив французької як мови провідної в культурному відношенні нації Свропи німецька мова настільки «збагатилася» запозиченнями, що постала загроза втрати нею своєї самостійності. Запозичення цього часу стосувалися різних сфер життя, серед яких сфера дипломатії та державного управління (Depesche, Minister), торгівлі (engagieren, Fabrik), транспорту (Karosse, Equipage), гастрономії (Bouillon, Kotelett, Konfitüre), моди (Frisur, Garderobe, Korsett), суспільної поведінки (Etikette, Kompliment, parlieren) тощо.

У ХІХ столітті провідну роль в Європі відіграє Великобританія, а тому саме англійська мова є джерелом запозичень. Це стосується не тільки 
бізнесових понять, але й лексики, що обслуговує сфери журналістики, транспорту та суспільного життя (Interview, Reporter, Tunnel, Tender, Kartell, Trust, Dandy, Flirt, Smoking, Coctail). Починається інтенсивне збагачення словникового складу німецької мови англіцизмами, цей процес триває ще донині. У XX столітті вплив англійської мови, особливо ії американського варіанта, значно зростає і поступово запозичення з'являються не тільки в суспільній, але й у приватній сфері. Так, слова Bestseller, Jazz, Make up, Pullover, Teenager відомі не тільки мові засобів масової інформації, літератури та економічних вісників, але й пересічним громадянам.

Отже, кожна значна епоха в історії розвитку людства залишала в німецькій мові свої сліди у вигляді запозичень. Більшість із них уже не сприймається суспільством як іншомовні слова, оскільки вони адаптувалися до вимог німецької мови. Ступінь асиміляції іншомовних слів у німецькій мові залежить від того, наскільки довго та як часто вони використовуються мовцями. Так, наприклад, такі слова як Engel, dichten, Fenster, Körper, Tisch, Flöte, Maske та інші мовці не пов'язують із процесом запозичення, у той час як Bibliothek, незважаючи на досить тривалий термін перебування в словниковому складі німецької мови та загальновживаний характер, ще й досі сприймається як запозичення.

Тож важливою, на наш погляд, залишається проблема визначення й тлумачення запозичення. Існують певні ознаки запозиченого слова. Серед них слід назвати в першу чергу такі:

- наявність у морфологічній структурі слова компонентів іншомовного походження (суфіксів та префіксів): impulsiv, Konzentration, Mobbing, reformieren;

- незвичайне, відмінне від звичного звучання слова, наприклад: Friseur, Тeam, або місце наголосу, що не відповідає вимогам німецької мови, наприклад: desolat, Dï̈t, prolongieren;

- графічна невідповідність, незвичайні для німецької мови графічні структури та сполучення літер: Bodybuilding, Soutane, Osteoporose, Philosophie.

Наведені вище ознаки іншомовних слів дають змогу виявити запозичення, але не в усіх випадках. Слід зауважити, що префікс $\boldsymbol{a b}$ - та суфікс ier y різних словах може бути свідченням того, що слово запозичене, але не завжди (absolut-abreisen, massakieren - erfrieren). Крім того, до деяких німецьких коренів часто додаються запозичені афікси (buchstabieren, Schwulität, hausieren), і навпаки, до запозичених коренів іноді додаються німецькі суфікси та префікси (Direktheit, temperamentvoll, risikoreich). Такі гібридні словоутворення вже не можна однозначно віднести ані до іншомовних слів, ані до автентичної лексики.

Варто звернути увагу також і на ту обставину, що значна кількість запозичених слів вимовляється відповідно до фонетичних вимог німецької мови, тому такі одиниці вже не сприймаються як запозичені (Spekulant, 
Stadium; Stil, Atlas, Lyrik, Radio, Thema). Більшість асимільованих слів важко виявити через те, що вони не тільки вимовляються, але й пишуться у німецькій традиції письма (Keks, schocken). Процес визначення запозичень у мові ускладнює ще й те, що від високої частоти вживання слова іншомовного походження стали звичними й увійшли до основного словникового фонду мови і тому не сприймаються як запозичені. Серед них Auto, Karussell, Möbel, Salat, Paradies, interessieren, Kasse, Pause, Tunnel тощо. Отже, як бачимо, межі між запозиченим та суто німецьким словом хиткі, а критерії визначення запозичення неточні і потребують подальшої деталізації та концептуального аналізу.

Більш важливою, з нашої точки зору, є не проблема існування в мові значної кількості запозичень, а особливості їх використання. Функціонування того чи іншого слова в мовленні зумовлено в більшості випадків не його походженням, а інтенцією мовця. Від того, який вплив має здійснити на реципієнта обране мовцем слово, залежить і його вибір. Тож, питання використання запозичень - це питання стилю та комунікативної спрямованості, комунікативного завдання висловлювання. Завдяки деталізації змісту запозичення можуть викликати в певних контекстах специфічні асоціаціï, давати ціннісну характеристику, унаочнювати та деталізувати суб' єктивне ставлення мовця до подій, явищ, людей саме через відбір лексики (Exkursion - Ausflug; simpel - einfach; Praktikum- Übung; autokratisch selbstherrisch). Іноді використання запозичень уникнути взагалі неможливо, зокрема, якщо постає необхідність створити певний локальний чи країнознавчий колорит (Kreml, Torero, Bango) або через відсутність аналога в німецькій мові. Досить часто в розмовній мові використання іншомовних слів викликане необхідністю передати певний душевний стан, бажанням здаватися більш сучасним, більш динамічним, більш обізнаним. Особливо це типово для молодіжної мови, наприклад: «Ich muss nur eben noch schnell mein Handy catchen, dann sind wir weg, okay?».

Використання запозичень у певному контексті часто зумовлюють стильові відмінності тексту. Так, використання Portier замість Pförtner або Hauswart надає особі більшої ваги, а transpirieren замість schwitzen сприймається менш забарвленим. Запозичення надають тексту певних стилістичних ознак, вони здатні віднести його до певного стилістичного рівня: високого (Preziosen - Schmuckstücke), нейтрального (produzieren - fertigen), низького (Job - Arbeit, cool - sehr gut, Appeal - Ausstrahlung). Використання іншомовних слів може виражати суб'єктивне ставлення мовця, яке містить як позитивні, так і негативні конотації (phänomenal - außergewöhnlich, professionell - beruflich, Visage - Gesicht).

Слова іншомовного походження часто мають певний спеціальний зміст, який наближає їх до термінологічної лексики. Уживання таких запозичень має на меті пом'якшити обговорення гострих, табуйованих або просто неприємних тем, таких як хвороба (Psychiatrie - Irrenanstalt), 
смерть (letal-tödlich, Exitus - Tod), провали або невдачі у професійній сфеpi (illiquid-pleite).

Ще одна функція запозичень - натяк на певний аналогічний випадок в історії, символічний зміст, проведення паралелі, порівняння тощо. У таких випадках мовець апелює до фонових знань співрозмовника, висуває до нього певні освітні вимоги: Judaslohn, Pyrrhussieg, Tantalusqualen.

У сфері комунікації, рекламі та бізнесі слова іншомовного походження найбільш продуктивні. Це пов'язано з наявністю значної кількості термінів та $з$ прагненням до лаконічності й дієвості. Але іноді використання запозичених слів зумовлено просто прагненням звернути на щось увагу, виділити або підкреслити (Businessclass, Servicepoint, Sounddesigner, Workshop, Broker).

Запозичення не завжди зайві, досить часто вони дозволяють уникнути повторів і тим самим урізноманітнити мову. Можна навести такі синонімічні пари: Enthaltsamkeit - Abstinenz, Feinkost - Delikatessen, Mundart Dialekt, Nachtisch - Dessert, Rechtschreibung - Orthographie, Reifezeugnis Abitur, Wochenende - Weekend. Варіативність можлива не лише на лексичному, але й на синтаксичному рівні. Так, наприклад, речення «Er führt oft einen Ausspruch seiner Frau an« можна без втрат змісту замінити еквівалентом «Er zitiert oft seine Frau«. Така заміна не тільки позбавляє речення рамкової конструкції, але й скорочує його, що $є$ досить суттєвим з точки зору економії мовних засобів вираження змісту.

Запозичення в німецькій мові піддаються певним змінам і досить швидко асимілюються. Це відбувається не тільки на лексичному рівні, але й на рівні граматики. Англійські запозичення досить легко отримують рід та категоріальні ознаки, утворюють словоформи та слугують матеріалом для утворення нових слів за рахунок словотвірних можливостей німецької мови. Нетипові для німецької мови звуки та звукосполучення передаються схожими за звучанням звуками. Так, наприклад, англійське слово poster відрізняється від німецького Poster протиставленням [ou]-[o]. Сполучення sp st у запозичених з англійської словах читаються за правилами орфоепії німецької мови (Stadium, Station).

Слова, запозичені з англійської мови, швидко асимілюються в німецькій завдяки словотвірним можливостям останньої і на граматичному рівні. Так, додаванням інфінітивного закінчення -en утворені дієслова faxen, picknicken, palavern та інші. На побутовому рівні можна знайти утворені цим шляхом дієслова, що набувають образності, відповідники до яких навряд чи можливі в українській мові, наприклад googeln, jobben, mailen,. Особливо продуктивними $є$ запозичення з галузі техніки, комп'ютерних технологій, світу Інтернету, наприклад: downloaden, updaten, які наділяються ознаками слабких дієслів і відповідно утворюють часові форми (loadete down, hat downgeloadet). 
Серед запозичень $є$ слова зі зміщеним змістом, тобто англіцизми, зміст яких відрізняється від аутентичного, наприклад: der Boy - гомосексуаліст, das Groupie - дівчина-фанатка зірки, актриси, спортсмена тощо.

Таким чином, запозичення відіграють дуже важливу роль у німецькій мові. Вони становлять значний обсяг словникового складу і виконують різноманітні функції. Слова іншомовного походження потрапляють до німецької мови різними шляхами, найчастіше шляхом матеріальних та лексичних запозичень, i досить швидко асимілюються на фонетичному, морфологічному та граматичному рівнях. На комунікативному рівні запозичення можуть виконувати різні функції, серед яких слід назвати в першу чергу номінативну, коли запозичення називають предмети та явища, що не мають відповідностей у німецькій мові; конкретизуючу, коли запозичення виконують схожу з термінами роль, а також стилістичну. Німецькі запозичення дуже продуктивні у процесі словотвору. Вони здатні утворювати нові слова за допомогою іншомовних коренів з додаванням німецьких афіксів, німецьких коренів та іншомовних афіксів, різноманітних трансформацій автентичного значення. Найбільш багатою на запозичення сферою $\epsilon$ сфера комунікації, засобів масової інформації, техніки, комп'ютерних технологій, економіки тощо. Запозичення такого роду, як правило, дуже швидко поширюються на побутовий рівень 3 певним зміщенням лексичного значення.

\section{Список використаної літератури}

1. Большой толковый словарь немецкого языка: Для изучающих немецкий язык / Langenscheidts Großwörterbuch Deutsch als Fremdsprache. - М.: Издательство Март, 1998. - $1248 \mathrm{c}$.

2. Duden: Richtiges und gutes Deutsch: Wörterbuch der sprachlichen Zweitelsfälle. Mannheim; Leipzig; Wien; Zürich: Dudenverlag, 1997 / Der Duden: Bd. 9. - 860 S.

3. Duden: Fremdwörterbuch. - Mannheim; Leipzig; Wien; Zürich: Dudenverlag, 1997. - Der Duden: Bd.5. - 864 S.

4. Duden. Sinn- und sachverwandte Wörter. - Mannheim; Leipzig; Wien; Zürich: Dudenverlag, 1997. - Der Duden: Bd. 8. - 858 S.

5. Duden. Stilwörterbuch der deutschen Sprache. - Mannheim; Leipzig; Wien; Zürich: Dudenverlag, 1997. - Der Duden: Bd. 2. - 864 S.

6. Pons Wörterbuch der deutschen Umgangssprache. - REA, Ernst Klett Verlag für Wissen und Bildung GmbH, Stuttgart, 1987. - 959 S.

\section{Summary}

This article contents analyses of some questions of lexicology. It was studied the function and character of loan-words and ways of their phonetically, morphologically and grammatically adaptation in German. 